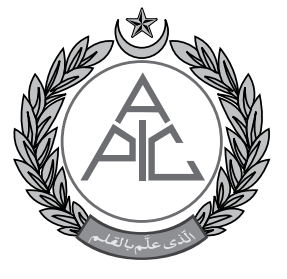

Assistant Professor, Department of Anesthesia, Mahatma Gandhi Medical College \& Research Institute, Sri Balaji Vidyapeeth, Pillayarkuppam, Pondicherry 607 402, (India)

Senior Resident, Department of Anesthesia, King George Medical University, Lucknow, Uttar Pradesh, 226003, (India)

Correspondence:

Dr Ram Gopal Maurya, MD, Senior Resident, Department of Anesthesia, King George

Medical University, Lucknow, Uttar Pradesh 226003, (India); Phone: 91-9559297075; E-mail: ramgopalkgmc@gmail.com

Received: 6 Oct 2018

Reviewed: 16 Oct 2018

Corrected: 28 Oct 2018

Accepted: 05 Nov 2018

\section{Calculating minimum nutrition requirements in ICU patients}

\author{
Indubala Maurya, MD, DNB ${ }^{1}$, Ram Gopal Maurya, $\mathrm{MD}^{2}$
}

\section{ABSTRACT}

Critically ill patients frequently receive inappropriate nutrition leading to underfeeding or overfeeding. This is associated with negative outcomes such as poor wound healing, difficulty in weaning from mechanical ventilation and an increase in mortality. This is due to due to lack of standard and appropriate formulas for calorie and protein calculation. We reviewed current evidence and recommendations for the minimum nutrition requirement for ICU patients.

Key words: Nutrition; ICU; Mechanical ventilation; Morbidity; Mortality

Citation: Maurya I, Maurya RG. Calculating minimum nutrition requirements in ICU patients Anaesth Pain \& Intensive Care 2018;22 Suppl 1:S106-S108

\section{INTRODUCTION}

Calculation of nutrition requirements in critically ill patients is essential to avoid overfeeding and underfeeding. Whether it is underfeeding or overfeeding, both of these are associated with adverse outcomes in critically ill patients. Underfeeding causes poor respiratory epithelium regeneration and respiratory muscles weakness which may lead to difficulty in weaning from mechanical ventilation..$^{1,2}$ It is also associated with an increased risk of infection and poor wound healing. ${ }^{3}$ While overfeeding is associated with hyperglycemia, fatty liver, increased physiological stress and prolongs the duration of mechanical ventilation due to increased carbon dioxide burden., ${ }^{2,4}$, To determine nutrition requirements for ICU patients can prove to be a challenging task for the new entrants in the specialty. Various predictive equations have been used for designing nutritional goals. However, those predictive equations are often unsuitable due to lack of validation in the ICU patients. ${ }^{3,6}$

\section{CALORIES CALCULATION}

Indirect calorimetry is a gold standard for the measurement of energy requirements. The principle for indirect calorimetry includes measurement of oxygen consumption in $\mathrm{ml} / \mathrm{min}\left(\mathrm{VO}_{2}\right)$ and carbon dioxide production in $\mathrm{ml} / \mathrm{min}\left(\mathrm{VCO}_{2}\right)$ using a conventional infrared technique or paramagnetic oxygen analysis. ${ }^{7}$ It provides an accurate assessment of energy expenditure during steady state condition. ${ }^{1,7,8}$, Though many equations such as Harris-Benedict equation, are available for estimating energy expenditure in the critically ill patient, but none of these is consistent and accurate in comparison to indirect calorimetry. ${ }^{69}$ These equations are affected by various patient-related variables like body composition, nutritional status, and ethnicity. But 
indirect calorimetry needs resources and expertise. Various calorimetry devices include metabolic carts, handheld devices, and built-in metabolic modules in modern ventilators. ${ }^{10}$ If Indirect calorimetry is not available, simple weight-based equation $(25-30 \mathrm{kcal} /$ $\mathrm{kg} / \mathrm{d}$ ) can be used to determine energy requirements. ${ }^{11}$ The energy expenditure should be reassessed more than once per week. In presence of edema, consider dry body weight for calorie calculation. In obese ICU patients, some amount of weight loss may increase insulin sensitivity and reduce the risk of comorbidities. ${ }^{12}$ Thus hypocaloric diet with high protein is recommended for obese ICU patients. For patients with body mass index 30-50, weightbased equation 11-14 kcal/kg actual body weight per day while $22-25 \mathrm{kcal} / \mathrm{kg}$ ideal body weight per day for BMI $>50$ is recommended. ${ }^{11}$ Any dextrosecontaining fluids and lipid-based medications e.g. propofol should be considered a source of calorie while designing nutrition regimens.

Protein requirement: Protein is most important for maintaining lean body mass, wound healing, and immune function. Protein requirement for critically ill patients calculated by weight based equation of $1.2-2.0 \mathrm{~g} / \mathrm{kg} /$ day body seems to be adequate for most ICU patients. ${ }^{11}$ Use of serum protein markers such as albumin, pre-albumin etc., are not reliable for assessment of the adequacy of protein balance in ICU patients. ${ }^{13}$ Patients with renal failure on haemodialysis should receive higher protein, maximum up to $2.5 \mathrm{~g} / \mathrm{kg} /$ day. More than $2.5 \mathrm{~g} / \mathrm{kg} /$ day is undesirable. ${ }^{14}$ Protein requirements for the patient with hepatic failure should be calculated using the same formula as for the general ICU patient considering dry weight. But, protein should not be limited as a part of management to reduce hepatic encephalopathy as it may have the adverse outcome. ${ }^{11 \text {, }}$

${ }^{17}$ Protein requirement for patients with burn injury is calculated by using formula $1.5-2 \mathrm{~g} / \mathrm{kg} /$ day. ${ }^{18}$ For obese patients, high protein hypocaloric diet is recommended. ICU patients with body mass index 30- 40, protein should be calculated using formula $2.0 \mathrm{~g} / \mathrm{kg}$ ideal body weight per day and $2.5 \mathrm{~g} / \mathrm{kg}$ ideal weight per day if BMI $>40 .{ }^{11}$

\section{MICRONUTRIENTS}

Essential traceelements and vitamins such as selenium, zinc, copper, vitamin B, C, D, and E are included in micronutrients. These are important for metabolism, cellular immunity, and antioxidant activity ICU patients may suffer micronutrient deficiencies due to pre-existing malnutrition, ongoing redox imbalance due to systemic inflammatory response syndrome. ${ }^{17}$, ${ }^{18}$ Patients on complete and balanced formula feeds may not require additional micronutrients. The micronutrients should be considered in cases of pre-existing deficiency, malabsorption syndrome, burns and patients on parenteral nutrition. Before micronutrient supplementation, renal function should always be evaluated. Due to insufficient data, there is no recommendation regarding dose, route and duration for micronutrients supplementation in the critically ill patients. ${ }^{11}$

\section{IMMUNEMODULATINGNUTRIENTS}

Immunemodulating nutrients such as arginine, eicosapentaenoic acid, docosahexaenoic acid, glutamine etc., should not be used routinely in ICU patients. ${ }^{11}$ Eicosapentaenoic acid (EPA or also icosapentaenoic acid) is an important polyunsaturated fatty acid found in fish oils. It serves as the precursor for the prostaglandin3- and thromboxane3-families. These additives can be considered in traumatic brain injury, ARDS and perioperative critically ill patients. ${ }^{19}$

\section{ANTIOXIDANTS}

Use of antioxidants (omega-3 fatty acids etc.) does not significantly reduce morbidity and mortality in ICU patients. In the presence of conflicting studies, formula feed with an anti-oxidants is not recommended. ${ }^{11}$

\section{DIETARY FIBER}

Use of mixed fibercontaining feed should not be used routinely in critically ill patients. ${ }^{11}$ After excluding use of hyperosmolar agent and C. difficile infection, patients with persistent diarrhea can get benefited with use of soluble fibercontaining formulas. ${ }^{11,20}$

\section{PROBIOTICS}

Routine use of probiotics in ICU patients is not recommended. ${ }^{12}$ It should be used only for specific patient e.g. pancreatectomy, liver transplantation etc., for which RCTs have shown outcome benefits. ${ }^{21,22}$

\section{CONCLUSION}

Nutritional requirements of the patient in ICU need to be carefully calculated, as under- as well as overfeeding, both can have adverse effects on the course of the disease. The main emphasis must be laid upon the caloric requirement, and in the essential amino acid and fatty acids. Only in selected patients other nutrients, e.g. micronutrient, immunemodulating nutrients, antioxidants and probiotics, may be required.

Conflict of Interest: Nothing to declare

Authors'contribution:

IM: Concept, Manuscript editing

RGM: Manuscript writing 


\section{REFERENCES}

1. Brandi LS, Bertolini R, Calafa M. Indirect calorimetry in critically ill patients: clinical applications and practical advice. Nutrition. 1997;13:349-58.

2. Brandi LS, Bertolini R, Santini L, Cavani S. Effects of ventilator resetting on indirect calorimetry measurement in the critically ill surgical patient. Crit Care Med. 1999;27:531-9.

3. Dokken M, Rustoen T, Stubhaug A. Indirect calorimetry reveals that better monitoring of nutrition therapy in pediatric intensive care is needed. J Parenter Enteral Nutr. 2015 Mar;39(3):344-52.

4. Askanazi J, Carpentier YA, Elwyn $\mathrm{DH}$, et al. Influence of total parenteral nutrition on fuel utilization in injury and sepsis. Ann Surg. 1980a;191:40-6.

5. Kocache RMA, Swan J, Holman DF. A miniature rugged and accurate solid electrolyte oxygen sensor. J Phys Environ Sci Instrum. 1984;17:47782.

6. Hunter DC, Jaksic T, Lewis D, Benotti PN, Blackburn GL, Bistrian BR. Resting energy expenditure in the critically ill: estimations versus measurement. $\mathrm{Br} \mathrm{J}$ Surg.1988;75(9):875-8.

7. Weir JB. New methods for calculating metabolic rate with special reference to protein metabolism. J Physiol. 1949;109(1-2):1-9.

8. Lev S, Cohen J, Singer P. Indirect calorimetry measurements in the ventilated critically ill patient: facts and controversies - the heat is on. Crit Care Clin. 2010;26(4):1-9.

9. Daly JM, Heymsfield SB, Head CA, et al. Human energy requirements: overestimation by widely used prediction equation. Am J Clin Nutr. 1985;42(6):1170-4.

10. Rakesh Garg, Indubala Maurya. Calorimetry for Enteral Feeding in Critically III Patients. Diet and Nutrition in Critical Care. New York. Springer, 2014.

11. McClave SA, Taylor BE, Martindale RG, Warren MM, Johnson DR, Braunschweig $C$ et al. Guidelines for the Provision and Assessment of Nutrition Support Therapy in the Adult Critically III Patient: Society of Critical Care Medicine (SCCM) and American Society for Parenteral and Enteral Nutrition (A.S.P.E.N.). J Parenter Enteral Nutr. 2016 Feb;40(2):159211.

12. Choban PS, Burge JC, Scales D, Flancbaum L. Hypoenergetic nutrition support in hospitalized obese patients: a simplified method for clinical application. Am J Clin Nutr. 1997;66(3):546-550.

13. Davis CJ, Sowa D, Keim KS, Kinnare $K$, Peterson S. The use of prealbumin and $\mathrm{C}$-reactive protein for monitoring nutrition support in adult patients receiving enteral nutrition in an urban medical center. JPEN J Parenter Enteral Nutr. 2012;36(2):197-204.

14. Scheinkestel CD, Kar L, Marshall K, et al. Prospective randomized trial to assess caloric and protein needs of critically ill, anuric, ventilated patients requiring continuous renal replacement therapy. Nutrition. 2003;19(11-12):909-916.

15. Bemeur $C$, Desjardins $P$, Butterworth RF. Role of nutrition in the management of hepatic encephalopathy in endstage liver failure. J Nutr Metab. 2010;2010:489823.

16. Rousseau AF, Losser MR, Ichai $C$, Berger MM. ESPEN endorsed recommendations: nutritional therapy in major burns. Clin Nutr. 2013;32(4): 497-502.

17. Prelack K, Sheridan RL. Micronutrient supplementation in the critically ill patient: strategies for clinical practice. J Trauma. 2001;51(3):601-20.

18. Manzanares W, Dhaliwal R, Jiang $X$, Murch L, Heyland DK. Antioxidant micronutrients in the critically ill: A systematic review and meta-analysis. Crit Care 2012;16:66.

19. Kudsk KA, Moore FA. Consensus recommendations from the U.S. summit on immune-enhancing enteral therpay. JPEN J Parenter Enteral Nutr. 2001;25:S61.

20. Tarleton SM, Kraft CA, DiBaise JK. Fiber-enriched enteral formulae: Advantageous or adding fuel to the fire? Pract Gastroenterol 2013;124:11-22.

21. Rayes N, Seehofer D, Theruvath T, et al. Effect of enteral nutrition and synbiotics on bacterial infection rates after pylorus-preserving pancreatoduodenectomy: a randomized, double-blind trial. Ann Surg. 2007;246(1):36-41.

22. Zhang $\mathrm{Y}$, Chen J, Wu J, Chalson $\mathrm{H}$, Merigan L, Mitchell A. Probiotic use in preventing postoperative infection in liver transplant patients. Hepatobiliary Surg Nutr. 2013;2(3):142-147. 